\title{
Development of extruded snacks and corn flakes using yellow corn and by-product
} broken beans

\author{
Omaima M. Dewidar ${ }^{1}$ and Hanan M.A. EL ghandour ${ }^{2}$
}

\author{
${ }^{I}$ Department of Crops Technology Research, Food Technology Research Institute, Agriculture \\ Research Center, Giza, Egypt. \\ ${ }^{2}$ Regional Center for Food and Feed, Agriculture Research Center, Giza, Egypt
}

Received: 10 March 2020/ Accepted 15 June 2020 / Publication date: 30 June 2020

\begin{abstract}
The purpose of this paper is to investigate development of extruded snacks and corn flakes by using yellow corn and by-product broken white beans flour (BWBF). The methodology included in this paper is based on adding BWBF broken white beans flour $(10,20,30,40$ and $50 \%)$ as source of protein by a partial substitution of yellow corn flour and corn grits, all samples were evaluated for their physicochemical properties, minerals, amino acids content as well as sensory quality attributes, nutritional value compared with RDA and the production costs of different samples were also studied. The results indicated that BWBF percentage and also the extrusion condition (moisture and temperature) in flounced the physical color and functional (water absorption index and water solubility index) for corn Flakes and extruded snacks. The water activity was gradually decreased with increase adding BWBF in the blends for corn flakes and snacks. Therefore volume mass also density were significantly changed in the resultant corn flakes and snacks. Fortification with BWBF significantly increased in protein, ash, minerals and amino acids. While carbohydrates significantly decreased in corn flakes and snacks compared with control samples. corn flakes covers up to $38.85 \%$ of protein requirement, $22.6 \%$ and $25.43 \%$ of energy requirement for male and female, $29.44 \%$ of phosphorus requirement, $66.25 \%$ of iron requirement, $63.63 \%$ of zinc and $6.91 \%$ of calcium, for children. Whereas, snacks cover up to $33.44 \%$ of protein requirement, $22.57 \%$ and $25.39 \%$ of energy requirement for male and female, $28.86 \%$ of phosphorus requirement, $65.63 \%$ of iron requirement, $64.88 \%$ of zinc and $6.24 \%$ of calcium from RDA, for children of age 9-13 years. The fortification with $(10,20$ and 30\%) significantly enhanced attributes of resultant corn flakes and snacks. while 40 and $50 \%$ treatment a chivied low score of acceptability. Prices are very suitable for the Egyptian market, the investigated extrudates were cheaper than market products and high nutritive value. Therefore, it could be recommended to consume corn flakes and snacks to provide children with part of their daily requirements of protein, energy, phosphorus, calcium, iron and zinc.
\end{abstract}

Keywords: Extrusion, corn flakes, snacks, Yellow corn, broken kidney white beans, nutritional value.

\section{Introduction}

Corn flakes and snacks are ready-to-eat, convenient snack that are consumed by the young population groups in many countries. The development of food products using composite raw materials has increased and is attracting much attention from researchers; especially in the production of Extruded products (Forsido et al., 2019).

The increasing demand of the consumer market for new products stimulates the use of regional raw materials. The consumption of breakfast meals has increased considerably in recent years because products that are quickly prepared are in demand due to the lack of time characteristic of modern life (Bolanho et al., 2014). These products can be produced through thermoplastic extrusion according to Santos et al., (2020).

Extrusion cooking utilizes high temperature, high pressure, and high force to produce products with low density, high expansion and unique texture. In addition to the usual benefits of heat processing, extrusion offers the possibility of modifying the functional and rheological properties of food ingredients (Santos et al., 2020). Food extrusion were among the most commercially successful extruded foods. The extruded foods market has been increasing rapidly worldwide. Extrusion is a process of industrial cooking that combines moisture, high pressure, heat and mechanic friction for a

Corresponding Author: Omaima M. Dewidar, Department of Crops Technology Research, Food Technology Research Institute, Agriculture Research Center, Giza, Egypt.

E-mail: omaima.dewidar@yahoo.com 
short period, causing physical and chemical alterations in the foods in order to benefit their technological characteristics (Carreiro et al., 2008).

Extrusion is currently one of the most important food processing technologies that has the potential to be utilized for this purpose. The hightemperature-short-time (HTST) process employed during extrusion ensures the product safety without significantly altering the nutritional value (Arêas, Rocha-Olivieri, \& Marques, 2016). Nevertheless, most extruded products are nutritionally inadequate due to the domination of starchy carbohydrates over its composition. Therefore, it allows the opportunity to integrate plant byproducts in an attempt to diversify the nutrients content of the extrudates. Past researches have successfully added plant by-products in extruded snacks and energy bars, with the main aims of improving nutritional value.

These days, predominantly, yellow corn was used as raw material for the manufacture of corn flakes and snacks. It is a source of nutrition as well as phytochemical compounds. It contains various major phytochemicals such as carotenoids, phenolic compounds, and phytosterols (Rouf Shah et al., (2016). The production of yellow corn in Egypt was (193810) tons according to Bulletin of The Agricultural Statistics (2018).

The general trend towards the use of by-products as some residues of agricultural crops such as broken white beans, broken chickpea seeds, broken rice, wheat germ, wheat bran, rice bran and etc, as by-products in the nutritional manufacture is increasing worldwide (Abd Rabo et al., 2019).

Broken white beans are the wests of process of extracting beans seeds from their dry horns. Broken beans, fragmented part of seeds, are often neglected by the industry. Although they cost five times less than whole ones, and present similar nutritional characteristics, the broken seeds represent a serious economic problem, but show technological importance (Carvalho et al., 2012a). Due to inherent physical and chemical characteristics, an alternative to add value to broken beans, and minimize the economic losses, would be the production of extruded broken beans flour (EBF) from this by-product.

Increasing amount of waste is generated from the crops processing industry (Sagar et al., 2018). This creates a major concern over its management and disposal, due to the negative impact on the natural resources (Kummu et al., 2012). However, most plant food-derived byproducts, such as broken white beans, are rich in nutrients, and therefore can be utilized to manufacture high nutrition value foods.

Dry beans (Phaseolus vulgaris L.) or common beans have been characterized as a nearly perfect food because of their high protein, fiber, prebiotic, vitamin B, and chemically diverse micronutrient composition. It is used throughout the world representing $50 \%$ of the seed legumes consumed as a human food source (Camara et al., 2013). According to Agriculture Directorates of Governorates statics (2015), the production of white beans in Egypt was 95970 tons and the loses was (6.12) according to Bulletin of The Agricultural Statistics (2018).

The combination of cereals and legumes could be an alternative to develop snack foods with increased nutritional compounds for promoting healthy benefits. Cereal and legume diets make up the bulk of caloric sources for a majority of households in the developing world. They contain macro- and micronutrients as well as phytochemicals embedded as one matrix Kamau et al (2020). Also beans are source of protein rich in lysine (Rezende et al., 2018). While corn protein provides an important amount of sulfur amino acids.

Therefore, the present study aimed to develop extruded snacks and breakfast meals corn flakes enriched with broken beans flour. The utilization of beans loses in manufacture high nutrition value foods and low costs.

\section{Materials and Methods}

\section{Source of Material:}

Ingredients e.g. yellow corn was obtained from Dar Elbasha factory, Qusena City, Menofya governorate Egypt. Broken kidney white bean seeds was obtained from Horticulture Research Institute, Agriculture Research Center, Ministry of Agriculture, Giza, Egypt, sugar and salt were obtained from local markets at Giza, Egypt. 


\section{Preparation of raw Material:}

Yellow corn grains divided two parts. In the first part, the grains were milled to get whole meal flour for corn flakes preparation. In the second part, the yellow corn grains were crunched after removed the pericarp and germ to get cruncher corn for snacks preparation and then packed in polyethylene bags and kept at a room temperature until used. Broken white bean soaked in tap water (1:3) for $18 \mathrm{~h}$., Drain the soaking water, Rinse the soaked broken seeds twice with tap water, dried in oven on $55-60{ }^{\circ} \mathrm{C}$ over night.

\section{Production of flour:}

Dry yellow corn grains and dry cleaned broken white bean seeds were milled in Eleman miller, Saqqara at Giza, Egypt (using standard electric grinder, Janke and Kunkel Type: MFC, Germany) to get whole meal flour 60 mesh sieve was used to get fine flour. The resulting flour was stored at room temperature $\left(28^{\circ} \mathrm{C}\right)$ in a high density polyethene bag for corn flakes and snacks preparation. The proximate composition of the flours was determined using AOAC (2016) methods.

\section{Flour blending:}

The method reported by Nwabueze et al. (2008) and Ocheme et al. (2011) was adopted for the blending. The blending was in ratio of 10,20,30,40 and 50\% (broken white bean flour added to yellow corn flour and yellow corn grits) Table (1).

\section{Sample preparation for extrusion:}

The raw materials (yellow corn flour and broken white beans flour) was separately brought to $40 \%$ water addition through material balance. The prepared samples were extruded at selected constant extrusion condition: screw speed of $800 \mathrm{rpm}$ and barrel temperature of $175-180^{\circ} \mathrm{C}$ in a Brabender a twin-screw extruder (Yuninan Daily Extrusion, Yunnan, Republic of China).

Table 1: Ingredients \% of Corn Flakes and Snacks.

\begin{tabular}{|c|c|c|c|c|c|c|c|c|c|c|c|c|}
\hline \multirow[b]{2}{*}{ Ingredients \% } & \multicolumn{4}{|c|}{ Corn Flecks } & \multirow[b]{2}{*}{ T 4} & \multirow[b]{2}{*}{ T 5} & \multicolumn{5}{|c|}{ Snacks } & \multirow[b]{2}{*}{ S 5} \\
\hline & T0 & T 1 & T 2 & T 3 & & & S O & S 1 & $\mathbf{S 2}$ & S 3 & S 4 & \\
\hline $\begin{array}{l}\text { Yellow corn } \\
\text { flour }\end{array}$ & 100 & 90 & 80 & 70 & 60 & 50 & --- & --- & --- & --- & --- & --- \\
\hline $\begin{array}{l}\text { Yellow corn } \\
\text { grits }\end{array}$ & --- & --- & --- & --- & --- & & 100 & 90 & 80 & 70 & 60 & 50 \\
\hline $\begin{array}{l}\text { Broken beans } \\
\text { flour }\end{array}$ & --- & 10 & 20 & 30 & 40 & 50 & --- & 10 & 20 & 30 & 40 & 50 \\
\hline Sugar & 7 & 7 & 7 & 7 & 7 & 7 & --- & --- & --- & --- & --- & -- \\
\hline Salt & 1 & 1 & 1 & 1 & 1 & 1 & 1 & 1 & 1 & 1 & 1 & 1 \\
\hline Water & 40 & 40 & 40 & 40 & 40 & 40 & --- & --- & --- & --- & --- & --- \\
\hline
\end{tabular}

T0:100\% corn flour and zero $\%$ BWBF. T1: $90 \%$ corn flour and 10\% BWBF. T2: $80 \%$ corn flour and 20\% BWBF. T3: $70 \%$ corn flour and 30\% BWBF. T4: 60\% corn flour and 40\% BWBF. T5: 50\% corn flour and 50\% BWBF. S: $: 100 \%$ corn grits and zero $\%$ BWBF. $\mathbf{S}_{1}: 90 \%$ corn grits and $10 \%$ BWBF. $\mathbf{S}_{2}: 80 \%$ corn grits and $20 \%$ BWBF. $\mathbf{S}_{3}: 70 \%$ corn grits and 30\% BWBF. S 4 : $60 \%$ corn grits and 40\% BWBF. S 5 : 50\% corn grits and 50\% BWBF.

Table 2: Proximate chemical composition of raw materials.

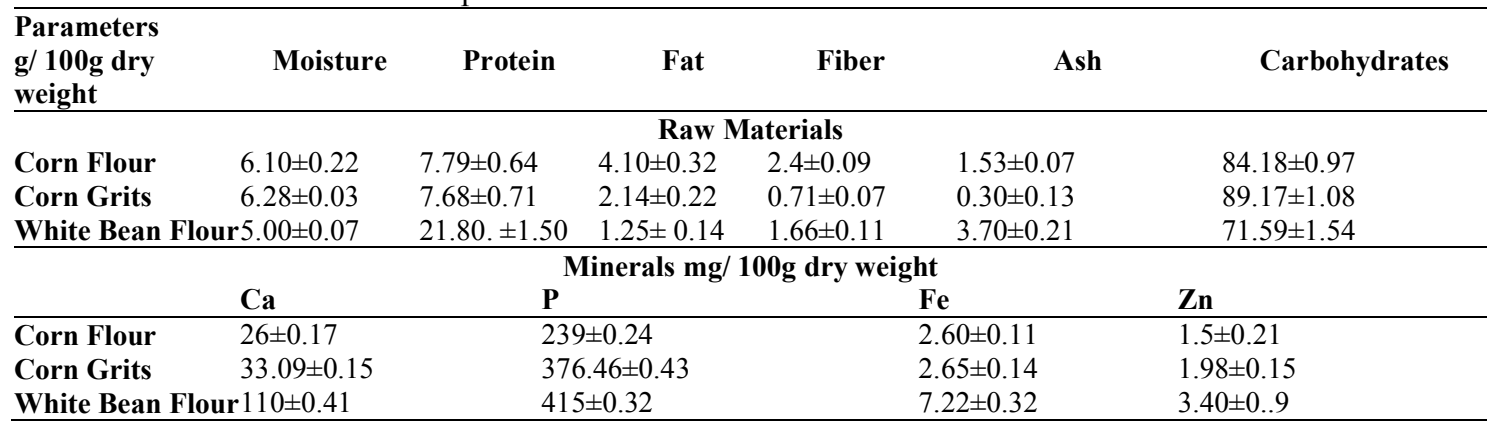




\section{Flake Manufacture:}

The flour blend (corn flour and broken white beans flour) was mixed with $40 \%$ water then sugar and salt were added in a mixer with paddle for $1 \mathrm{~min}$. The dough was placed in a pasta extruder attachment (Yuninan Daily Extrusion, Yunnan, Republic of China). As the dough was extruded it was cut into approximately $1.5 \mathrm{~cm}$ long pellets, trayed, and steamed at $18 \mathrm{psi}$ for $20 \mathrm{~min}$. After cooking, the pellets were tempered at $5{ }^{\circ} \mathrm{C}$ then placed in a circulating air oven at $40{ }^{\circ} \mathrm{C}$ to reduce the moisture content to $20 \%$ The partially dried pellets were flaked through heavily spring- loaded 10 -in. diameter steel rollers, with minimum gap of $0.05 \mathrm{~mm}$ The resulting flakes were toasted on pans at $215^{\circ} \mathrm{C}$ for $3.5 \mathrm{~min}$, cooled, and bagged for storage. The final moisture was kept below 5\% Lu and Walker (1988) for corn flakes.

\section{Snacks Manufacture:}

The blends (corn grits and broken white beans flour) were mixed with $1 \%$ salt in a mixer with paddle for $1 \mathrm{~min}$. The blend was placed in a extruder (a single extruder American type, American extrution) at different extrusion condition as follow

-Temperature of extruder was $180-210^{\circ} \mathrm{C}$.

-Screw speed $900 \mathrm{rpm}$.

-Feeding rate 1.8 and $2 \mathrm{~kg} / \mathrm{min}$ for snacks.

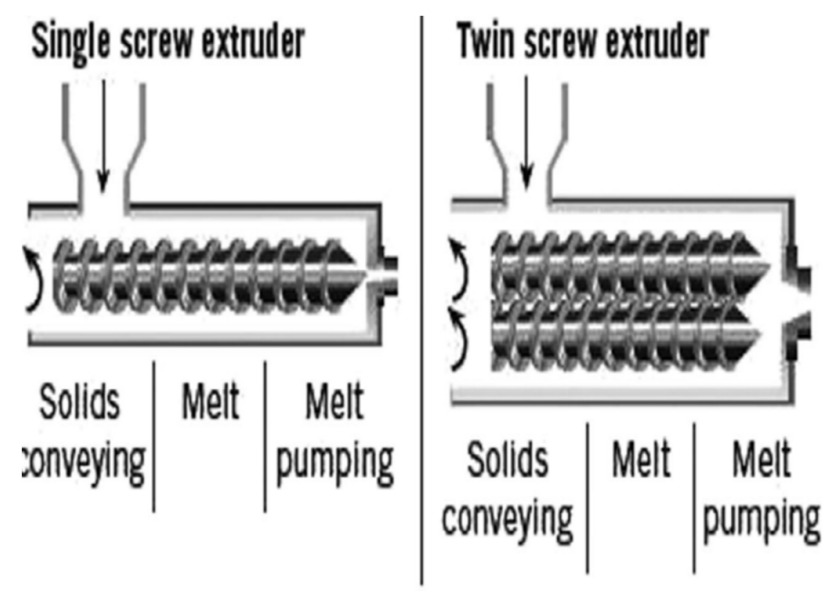

Particle sciences

Fig. 1: A cross section of single screw (left) and twin screw (right) extruder barrels.

\section{Physical properties of prepared corn flakes and snacks:}

\subsection{Color:}

The flakes and snacks colors were measured by objective colorimeter Chroma meter (CR-400, Konica, Minolta, Tokyo, Japan) and was determined according to the procedure previously described by Filipović et al. (2015).

\subsection{Water activity:}

Water activity ( $\left.{ }^{a} \mathrm{w}\right)$ was measured with a Rotronic Hygro Lap EAI0.SCS Switzerland ${ }^{\mathrm{a}} \mathrm{w}$ meter the measurements were performed in triplicate.

\subsection{Water absorption index (WAI) and Water solubility index (WSI):}

Water absorption index (WAI) and Water solubility index (WSI) of the extruded snacks and corn flakes were determined by previously described method (Anderson et al., 1969).

\subsection{Expansion Ratio (ER):}

Expansion Ratio (ER) was determined according to Kaludjerski and Filipovic (1998) and Kannadhason et al., 2009), where it was calculated as follows: 
$\mathrm{ER}=$ flakes volume $/$ crude flakes volume and $\mathrm{ER}=$ diameter of snacks $/$ diameter of die nozzle extruder.

\subsection{Density:}

Density was measured by divided Volume mass $/ 1000$. Volume mass for corn flakes and snacks was analyzed using $1 \mathrm{~L}$ baker with marks and scale ACCULAB L-Series. 1L baker was put no scale, tarred and extruded sample was poured in till its mark. Mass was recorded in three repetitions and average was calculated (Liene and Sandra, 2016).

\section{Chemical analysis:}

Moisture, protein, fat, crude fibers, ash and minerals contents of corn flakes and snacks samples were measured according to the AOAC (2016). Total carbohydrate was calculated by difference. Total calories were calculated as mentioned by Kerolles (1986) according to the following equation Total calories $=4$ (protein + Carbohydrates) +9 (fat)

\section{Determination of amino acids:}

Determination of amino acids was determined according to the method described in AOAC (2016) by using High Performance Amino Acid Analyzer. Chemical Score was calculated according to FAO (1991).

$$
\mathrm{C} . \mathrm{S}=\frac{\mathrm{mg} \text { of essential amino acid in } \mathrm{g} \text { test protein }}{\mathrm{mg} \text { of essential amino acid in requirement pattern }}
$$

\section{Sensory evaluation of corn flakes and snacks:}

Sensory evaluation of the corn flakes and extruded snacks products were carried out at Food and Feed Research Institute, by ten panelists according to Kosutic et al. (2016) and Al Subhi (2014) for determining the variation of the tested attributes (taste, odor, texture, color and overall acceptability) of corn flakes and snacks. The panelists were provided with corn flakes and snacks on a white plate at ambient temperature.

\section{Production Costs:}

They were evaluated according to Kabil (2016).

\section{Statistical analysis:}

Statistical analysis was carried out by SPSS Vr. 20 program. Data were expressed as means \pm S.D. and the statistical analysis were performed using one-way analysis of variance followed by Duncan's tests. (SPSS, 20) IBM Corp. Released (2011).

\section{Results and Discussion}

\section{Physical properties of corn flakes and extruded snacks:}

Table (3) shows the color parameters $\mathrm{L}^{*}, \mathrm{a}^{*}$, and $\mathrm{b}^{*}$ for the corn flakes and extruded snacks as a function of the percentage of beans flours. This parameter (lightness $L^{*}$ were $L^{*}=0$, black; $L^{*}=100$, white), is important because consumers are more familiar with snacks of light color, such as corn or potato chips. $L^{*}$ value of S5 was 61.51 which is lower than that of S0 (70.67). These results agree with work by Gomes et al., (2015) who explained the luminosity reduction to be a result from the extrusion process. The same is true for corn flakes samples, where $\mathrm{L}^{*}$ was reduced from 68.42 for $\mathrm{T} 0$ to 56.12 for $\mathrm{T} 5$.

The color coordinates a* observed an increase with the increase in the percentage of bean flour T0 was 0.61 while T5 increased to be 5.77. Corn flakes sample follow the same trend. This can be, also, explained by the extrusion process caused a darkening of the product, chromaticity coordinates $\mathrm{a}^{*}$ to increase. The color acquired by bean flour BF may be the result of sugar caramelization or the occurrence of Maillard reaction, since beans flour presents a large quantity of carbohydrates and proteins (Pelembe et al., 2002; Carreiro et al., 2008). b* value of T5 was 39.01 which is lower than that of T0 (56.06) . The same is true for extruded snacks samples where $b^{*}$ was reduced from 25.97 for S0 to 19.77 for S5. 
It is known that under extrusion, the changes in color can be attributed to the development of chemical reactions like browning, and that the extending of such reactions depends on the residence time and the temperatures in the extruder. ${ }^{a} \mathrm{~W}$ is shown in the same table.

Table 3: Color parameters and water activity for corn flakes and extruded snacks.

\begin{tabular}{ccccc}
\hline Treatment $^{*}$ & \multicolumn{1}{l}{$\boldsymbol{L}^{*}$} & $\boldsymbol{a}^{*}$ & $\boldsymbol{b}^{*}$ & ${ }^{\text {a }}$ \\
\hline & & \multicolumn{2}{c}{ Corn Flakes } \\
T0 & $68.42 \pm 0.20 \mathrm{a}$ & $0.61 \pm 0.10 \mathrm{f}$ & $56.06 \pm 0.05 \mathrm{a}$ & $0.39 \pm 0.00 \mathrm{a}$ \\
T1 & $67.06 \pm 0.16 \mathrm{~b}$ & $1.90 \pm 0.05 \mathrm{e}$ & $50.31 \pm 0.10 \mathrm{~b}$ & $0.38 \pm 0.01 \mathrm{a}$ \\
T2 & $65.49 \pm 0.09 \mathrm{c}$ & $2.44 \pm 0.10 \mathrm{~d}$ & $46.03 \pm 0.07 \mathrm{c}$ & $0.36 \pm 0.01 \mathrm{~b}$ \\
T3 & $64.01 \pm 0.14 \mathrm{~d}$ & $4.87 \pm 0.12 \mathrm{c}$ & $42.73 \pm 0.12 \mathrm{~cd}$ & $0.35 \pm 0.00 \mathrm{bc}$ \\
T4 & $64.52 \pm 0.10 \mathrm{~d}$ & $5.23 \pm 0.06 \mathrm{~b}$ & $40.61 \pm 0.14 \mathrm{~d}$ & $0.35 \pm 0.01 \mathrm{bc}$ \\
T5 & $56.12 \pm 0.76 \mathrm{e}$ & $5.77 \pm 0.10 \mathrm{a}$ & $39.01 \pm 0.09 \mathrm{~d}$ & $0.34 \pm 0.01 \mathbf{c}$ \\
\hline & & \multicolumn{2}{c}{ Extruded Snacks } \\
S0 & $70.67 \pm 0.29 \mathrm{a}$ & $0.46 \pm 0.21 \mathrm{e}$ & $25.97 \pm 0.40 \mathrm{a}$ & $0.40 \pm 0.00 \mathrm{a}$ \\
S1 & $69.87 \pm 0.28 \mathrm{~b}$ & $0.66 \pm 0.05 \mathrm{de}$ & $25.76 \pm 0.24 \mathrm{a}$ & $0.40 \pm 0.00 \mathrm{a}$ \\
S2 & $66.81 \pm 0.20 \mathrm{c}$ & $0.74 \pm 0.03 \mathrm{~d}$ & $23.22 \pm 0.21 \mathrm{~b}$ & $0.38 \pm 0.01 \mathrm{~b}$ \\
S3 & $65.51 \pm 0.11 \mathrm{~d}$ & $1.24 \pm 0.12 \mathrm{c}$ & $21.51 \pm 0.12 \mathrm{c}$ & $0.37 \pm 0.01 \mathrm{~b}$ \\
S4 & $64.22 \pm 0.21 \mathrm{e}$ & $3.03 \pm 0.16 \mathrm{~b}$ & $20.94 \pm 0.05 \mathrm{~d}$ & $0.36 \pm 0.00 \mathrm{c}$ \\
S5 & $61.51 \pm 0.16 \mathrm{f}$ & $5.32 \pm 0.22 \mathrm{a}$ & $19.77 \pm 0.14 \mathrm{e}$ & $0.36 \pm 0.01 \mathrm{c}$ \\
\hline
\end{tabular}

*See Table (1) for details. Values are mean \pm SD; Values are taken in triplicate Alphabets with different superscripts shows significant difference at $5 \%$ level of significance

Physical properties such as water activity for prepared products are illustrated in Table (4). There were ranged from 0.34 to 0.39 and from 0.36 to 0.40 respectively in ${ }^{a} \mathrm{w}$ in all samples for two products.

Lewicki et al. (2007) demonstrated that the range of water activity from 0.3 to 0.5 the crunchiness index for corn flacks was constant. At lower water activities, it decreased with increasing wetness of the material, but at higher water activities was close to zero. Li et al. (1998) mentioned that increase of water activity above 0.5 caused progressive loss of crispness.

Table 4: Physical properties of corn flakes and extruded snacks.

\begin{tabular}{|c|c|c|c|c|c|}
\hline Treatment* & Moisture & $\begin{array}{c}\text { Water Absorption } \\
\text { Index }\end{array}$ & $\begin{array}{c}\text { Water Solubility } \\
\text { Index }\end{array}$ & Expansion Ratio & Density \\
\hline \multicolumn{6}{|c|}{ Corn Flakes } \\
\hline T0 & $5.00 \pm 0.03 \mathrm{f}$ & $3.83 \pm 0.04 \mathrm{a}$ & $32.27 \pm 0.01 \mathrm{f}$ & $6.40 \pm 0.02 \mathrm{a}$ & $0.26 \pm 0.07 \mathrm{e}$ \\
\hline T1 & $5.11 \pm 0.05 \mathrm{e}$ & $3.81 \pm 0.02 \mathrm{a}$ & $33.63 \pm 0.07 \mathrm{e}$ & $5.74 \pm 0.03 b$ & $0.27 \pm 0.05 \mathrm{~d}$ \\
\hline T2 & $5.31 \pm 0.07 \mathrm{~d}$ & $3.64 \pm 0.06 \mathrm{~b}$ & $34.07 \pm 0.02 \mathrm{~d}$ & $5.41 \pm 0.15 c$ & $0.28 \pm 0.08 c$ \\
\hline T3 & $5.58 \pm 0.04 \mathrm{c}$ & $3.43 \pm 0.08 \mathrm{c}$ & $36.43 \pm 0.03 \mathrm{c}$ & $5.09 \pm 0.08 \mathrm{~d}$ & $0.28 \pm 0.05 \mathrm{c}$ \\
\hline T4 & $5.69 \pm 0.02 \mathrm{~b}$ & $3.37 \pm 0.09 \mathrm{~d}$ & $38.01 \pm 0.07 \mathrm{~b}$ & $4.47 \pm 0.05 \mathrm{e}$ & $0.29 \pm 0.03 \mathrm{~b}$ \\
\hline T5 & $5.82 \pm 0.06 \mathrm{a}$ & $3.24 \pm 0.03 \mathrm{e}$ & $39.13 \pm 0.17 \mathrm{a}$ & $4.04 \pm 0.07 \mathrm{f}$ & $0.33 \pm 0.02 \mathrm{a}$ \\
\hline \multicolumn{6}{|c|}{ Extruded Snacks } \\
\hline So & $3.50 \pm 0.04 \mathrm{f}$ & $4.87 \pm 0.02 \mathrm{a}$ & $30.46 \pm 0.01 \mathrm{f}$ & $0.61 \pm 0.08 \mathrm{a}$ & $0.029 \pm 0.07 \mathrm{~d}$ \\
\hline S1 & $3.97 \pm 0.06 \mathrm{e}$ & $4.73 \pm 0.01 \mathrm{~b}$ & $31.33 \pm 0.05 \mathrm{e}$ & $0.50 \pm 0.02 \mathrm{~b}$ & $0.053 \pm 0.05 \mathrm{c}$ \\
\hline S2 & $4.04 \pm 0.05 \mathrm{~d}$ & $4.43 \pm 0.08 \mathrm{c}$ & $31.63 \pm 0.03 \mathrm{~d}$ & $0.44 \pm 0.04 \mathrm{c}$ & $0.060 \pm 0.07 \mathrm{~b}$ \\
\hline S3 & $4.13 \pm 0.11 \mathrm{c}$ & $4.32 \pm 0.03 \mathrm{~d}$ & $32.23 \pm 0.08 \mathrm{c}$ & $0.39 \pm 0.03 \mathrm{~d}$ & $0.063 \pm 0.03 b$ \\
\hline S4 & $4.26 \pm 0.02 b$ & $4.16 \pm 0.05 \mathrm{e}$ & $32.63 \pm 0.11 b$ & $0.33 \pm 0.05 \mathrm{e}$ & $0.66 \pm 0.01 b$ \\
\hline S5 & $4.34 \pm 0.08 \mathrm{a}$ & $4.03 \pm 0.07 \mathrm{f}$ & $33.23 \pm 0.04 \mathrm{a}$ & $0.28 \pm 0.03 \mathrm{f}$ & $0.071 \pm 0.04 a$ \\
\hline
\end{tabular}

*See Table (1) for details. Values are mean \pm SD; Values are taken in triplicate Alphabets with different superscripts shows significant difference at $5 \%$ level of significance.

The moisture content of products increases with the increase in white bean flour. Our results are lower than those reported by Estrada-Giron et al., 2015. This may be due to the high-water absorption of white beans. Ding et al. $(2005,2006)$ reported that the increase in moisture content of raw materials result in extradites with lower water absorption.

Water absorption index (WAI) ranged from 3.81 to $3.24 \mathrm{~g} / \mathrm{g}$ for corn flakes and 4.73 to $4.03 \mathrm{~g} / \mathrm{g}$ for extruded snacks compared with control was 3.83 and $4.87 \mathrm{~g} / \mathrm{g}$. Wojtowicz and Moscicki, (2014) reported no clear relationships between amount or type of legumes added and WAI values. WSI of extrudates increased with increase in white bean flour. Changes in WSI with incorporation of white bean flour can be attributed to change in composition of the blends. Jones et al. (2000) reported that fiber, starch and protein contents affect the WSI. Lopes et al., (2012) referred the solubility of a product 
to its chemical composition and the interaction between its constitution and water (depends greatly on proteins and starch). Universidade Estadual de Campinas, (2011) concluded that, may be the proteinwater interaction is much more relevant than the amylose/amylopectin-water relation for WSI, since the flours with higher protein levels have gradually presented higher solubility.

The values of expansion ratio ER found in this research decreased with the increase of white bean flour $(0.61$ for control to 0.28 for samples of snacks with $50 \%$ ) were lower than those reported for corn and rice starches (Bastos-Cardoso et al., 2007), probably due to the addition of white bean flour in the blend that decreased the ER. The low ER was attributed to content of bean flour, which contains high amounts of protein. As reported by Estrada-Girón et al., (2015), for soy protein concentrate, high levels (greater than 25\%) reduce the radial expansion of the extrudates. Aguilar-Palazuelos et al. (2012) reported that in general, proteins act as diluents and reduce expansion due to their ability to affect water distribution in the matrix, and to the fact that their macromolecular structure and conformation affect the extensional properties of extruded meal. Increase in white bean flour level in extruded snacks causes an increase in the bulk density values. The increase in bulk density with increasing white bean flour level could be, as reported by Yagc1 and Gogus (2008), due to the addition of increasing amounts of fiber and protein to the blend which might affect the extent of starch gelatinization and the rheological properties of the melted material in the extruder.While Algarni et al. (2019) explained that the increasing bulk density, caused by less expansion and more impact, was due to the presence of fiber particles which tended to rupture the cell walls before the gas bubbles had expanded to their full potential. Camire and King (1991) explained that the non-starch polysaccharides in fiber might bind water more tightly during extrusion than protein and starch did. This binding might inhibit water loss at the die and reduce expansion, and thus probably increase bulk density in his study on the protein and fiber supplementation effects on extruded cornmeal snack quality.

\section{Chemical composition of corn flakes and extruded snacks:}

Chemical composition of corn flakes and extruded snacks samples are presented in Table 5. It could be noticed that the addition of white bean flour resulted an increases in both protein and ash, but a decrease in all other parameters in corn flacks. While snacks samples were increased in protein, ash, fat and fiber. The change in chemical composition is a result of addition of white bean flour. Our results agree with work by Ramezani et al., (2013). Tharanathan and Mahadevamma, (2003) who explained that the protein increase in samples containing white bean flour bread is generally due to the higher protein content of legume next to grains. So, adding the white beans flour in different amounts to bread increased the quantity of protein.

Table 5: Chemical composition of corn flakes and extruded snacks.

\begin{tabular}{clll}
\hline \multirow{2}{*}{ Treatment $^{*}$} & \multicolumn{1}{l}{ Protein } & Fat & Fiber \\
\cline { 2 - 4 } T0 & $7.54 \pm 0.13 \mathrm{e}$ & $3.73 \pm 0.08 \mathrm{a}$ & $2.57 \pm 0.04 \mathrm{a}$ \\
T1 & $8.02 \pm 0.03 \mathrm{e}$ & $3.62 \pm 0.05 \mathrm{ab}$ & $2.51 \pm 0.03 \mathrm{a}$ \\
T2 & $10.66 \pm 0.22 \mathrm{~d}$ & $3.45 \pm 0.28 \mathrm{ab} \mathrm{c}$ & $1.92 \pm 0.06 \mathrm{~b}$ \\
T3 & $11.33 \pm 0.43 \mathrm{c}$ & $3.33 \pm 0.24 \mathrm{bc} \mathrm{d}$ & $1.86 \pm 0.05 \mathrm{~b}$ \\
T4 & $12.42 \pm 0.40 \mathrm{~b}$ & $3.26 \pm 0.11 \mathrm{~cd}$ & $1.67 \pm 0.06 \mathrm{c}$ \\
T5 & $13.21 \pm 0.37 \mathrm{a}$ & $3.07 \pm 0.06 \mathrm{~d}$ & $0.97 \pm 0.04 \mathrm{~d}$ \\
\hline & & Snacks & \\
S0 & $6.12 \pm 0.12 \mathrm{f}$ & $1.47 \pm 0.12 \mathrm{e}$ & $0.42 \pm 0.03 \mathrm{e}$ \\
S1 & $7.57 \pm 0.18 \mathrm{e}$ & $1.76 \pm 0.08 \mathrm{~d}$ & $0.47 \pm 0.06 \mathrm{e}$ \\
S3 & $8.31 \pm 0.12 \mathrm{~d}$ & $2.01 \pm 0.06 \mathrm{c}$ & $0.92 \pm 0.07 \mathrm{~d}$ \\
S4 & $9.83 \pm 0.15 \mathrm{c}$ & $2.07 \pm 0.06 \mathrm{c}$ & $1.13 \pm 0.11 \mathrm{c}$ \\
S5 & $10.37 \pm 0.08 \mathrm{~b}$ & $2.23 \pm 0.08 \mathrm{~b}$ & $1.34 \pm 0.09 \mathrm{~b}$ \\
\hline
\end{tabular}

*See Table (1) for details. Values are mean \pm SD; Values are taken in triplicate Alphabets with different superscripts shows significant difference at $5 \%$ level of significance. 
Table 5: Continued

\begin{tabular}{clcl} 
Treatment $^{*}$ & Ash & Carbohydrates & Calorie \\
\hline & & Corn flakes & \\
\hline T0 & $2.53 \pm 0.17 \mathrm{c}$ & $86.19 \pm 0.28 \mathrm{a}$ & $408.54 \pm 0.44 \mathrm{a}$ \\
T1 & $2.83 \pm 0.19 \mathrm{bc}$ & $85.51 \pm 0.29 \mathrm{a}$ & $406.81 \pm 0.89 \mathrm{~b}$ \\
T2 & $2.93 \pm 0.32 \mathrm{~b}$ & $82.95 \pm 0.27 \mathrm{~b}$ & $405.54 \pm 0.42 \mathrm{c}$ \\
T3 & $3.02 \pm 0.32 \mathrm{~b}$ & $82.31 \pm 0.36 \mathrm{~b}$ & $404.57 \pm 0.62 \mathrm{c}$ \\
T4 & $3.22 \pm 0.01 \mathrm{a} \mathrm{b}$ & $81.09 \pm 0.28 \mathrm{c}$ & $403.42 \pm 0.53 \mathrm{~d}$ \\
T5 & $3.47 \pm 0.06 \mathrm{a}$ & $80.23 \pm 0.78 \mathrm{~d}$ & $401.44 \pm 0.42 \mathrm{e}$ \\
\hline & & Snacks & \\
S0 & $0.31 \pm 0.10 \mathrm{e}$ & $92.07 \pm 0.43 \mathrm{a}$ & $406.09 \pm 0.07 \mathrm{ab}$ \\
S1 & $0.72 \pm 0.11 \mathrm{~d}$ & $89.95 \pm 0.21 \mathrm{~b}$ & $405.92 \pm 0.20 \mathrm{bc}$ \\
S2 & $0.97 \pm 0.08 \mathrm{c}$ & $88.69 \pm 0.12 \mathrm{c}$ & $406.20 \pm 0.16 \mathrm{a}$ \\
S3 & $1.32 \pm 0.08 \mathrm{~b}$ & $86.70 \pm 0.18 \mathrm{~d}$ & $405.37 \pm 0.09 \mathrm{c}$ \\
S4 & $1.57 \pm 0.12 \mathrm{a}$ & $85.84 \pm 0.13 \mathrm{e}$ & $404.87 \pm 0.12 \mathrm{~d}$ \\
S5 & $1.71 \pm 0.06 \mathrm{a}$ & $84.47 \pm 0.14 \mathrm{f}$ & $405.28 \pm 0.10 \mathrm{c}$ \\
\hline
\end{tabular}

\section{Minerals content of corn flakes and extruded snacks:}

Mineral content of corn flakes and snacks samples are presented in Table 6. Calcium, phosphorus, iron and zinc content were analyzed for all samples. The data indicated that in all samples mineral content of corn flakes and snacks samples increased with increasing broken bean flour addition compared with control samples. Calcium content for samples were found to be from 60.85 to 89.84 $\mathrm{mg} / 100 \mathrm{~g}$ for corn flakes and from 60.50 to $81.12 \mathrm{mg} / 100 \mathrm{~g}$ for snacks, results indicated that increased P with increasing broken bean flour addition compared with control samples and recorded from 296.90 to 367.95 and 295.80 to $360.80 \mathrm{mg} / 100 \mathrm{~g}$ compared with control samples were 227.89 and 247.12 $\mathrm{mg} / 100 \mathrm{~g}$ for corn flakes and snacks.

The contents of iron and Zinc ( $\mathrm{Zn}$ ), of samples were ranged from 3.43 to $5.30 \mathrm{mg} / 100 \mathrm{~g}$, 3.47 to $5.25 \mathrm{mg} / 100 \mathrm{~g}$. Zinc content was 2.28 to 5.04 and 2.20 to $5.19 \mathrm{mg} / 100 \mathrm{~g}$ compared with control samples which recorded 3.29 and 3.33, 1.48 and 1.42 for corn flakes and snacks.

Beans are essential source of micronutrients such as minerals and vitamins and considered superior to cereals as a source of micronutrients (Welch et al., 2000). Beans have the highest level of mineral content than other legumes. They are an important source of iron, zinc and phosphorous while other minerals are also found in appreciable amounts (Broughton et al., 2003; Shimelis and Rakshit, 2005). The level of iron is highest in beans with a range of $62.0-150 \mu \mathrm{g} / \mathrm{g}$, which is mostly present in nonheme form (Vadivel and Janardhanan, 2000). The levels of zinc and phosphorus in different beans varieties are found to be in the range of 10.1-109 and 15.8-64.6 $\mu \mathrm{g} / \mathrm{g}$, respectively (Ojijo et al., 2000; Cabrera et al., 2003; Wu et al., 2005).

Table 6: Minerals content of corn flakes and extruded snacks (mg/100gm).

\begin{tabular}{|c|c|c|c|c|}
\hline Treatment* & $\mathbf{C a}$ & $\mathbf{P}$ & $\mathbf{F e}$ & $\mathbf{Z n}$ \\
\hline & \multicolumn{4}{|c|}{ Corn Flakes } \\
\hline T0 & $45.88 \pm 0.11 \mathrm{f}$ & $227.89 \pm 0.46 f$ & $3.29 \pm 0.07 \mathrm{e}$ & $1.48 \pm 0.09 \mathrm{f}$ \\
\hline T1 & $60.85 \pm 0.43 \mathrm{e}$ & $296.90 \pm 0.49 \mathrm{e}$ & $3.43 \pm 0.03 \mathrm{e}$ & $2.28 \pm 0.11 \mathrm{e}$ \\
\hline $\mathbf{T 2}$ & $68.99 \pm 0.28 \mathrm{~d}$ & $314.00 \pm 0.41 \mathrm{~d}$ & $3.95 \pm 0.07 \mathrm{~d}$ & $3.09 \pm 0.08 \mathrm{~d}$ \\
\hline T3 & $73.96 \pm 0.32 \mathrm{c}$ & $331.10 \pm 0.09 \mathrm{c}$ & $4.35 \pm 0.07 \mathrm{c}$ & $3.95 \pm 0.14 \mathrm{c}$ \\
\hline T4 & $80.80 \pm 0.31 \mathrm{~b}$ & $358.90 \pm 0.20 \mathrm{~b}$ & $4.95 \pm 0.15 b$ & $4.55 \pm 0.07 b$ \\
\hline \multirow[t]{2}{*}{ T5 } & $89.84 \pm 0.14 \mathrm{a}$ & $367.95 \pm 0.04 \mathrm{a}$ & $5.30 \pm 0.11 \mathrm{a}$ & $5.04 \pm 0.04 \mathrm{a}$ \\
\hline & \multicolumn{4}{|c|}{ Extruded Snacks } \\
\hline S0 & $44.75 \pm 0.13 f$ & $247.12 \pm 0.09 f$ & $3.33 \pm 0.07 \mathrm{e}$ & $1.42 \pm 0.07 \mathrm{f}$ \\
\hline S1 & $60.50 \pm 0.18 \mathrm{e}$ & $295.80 \pm 0.14 \mathrm{e}$ & $3.47 \pm 0.05 \mathrm{e}$ & $2.20 \pm 0.09 \mathrm{e}$ \\
\hline S2 & $69.92 \pm 0.05 \mathrm{~d}$ & $320.14 \pm 0.12 d$ & $3.90 \pm 0.08 \mathrm{~d}$ & $3.19 \pm 0.11 \mathrm{~d}$ \\
\hline S3 & $72.17 \pm 0.13 c$ & $340.12 \pm 0.12 \mathrm{c}$ & $4.30 \pm 0.11 \mathrm{c}$ & $3.90 \pm 0.19 \mathrm{c}$ \\
\hline S4 & $79.85 \pm 0.16 b$ & $352.90 \pm 0.08 b$ & $4.87 \pm 0.11 b$ & $4.57 \pm 0.12 b$ \\
\hline S5 & $81.12 \pm 0.10 \mathrm{a}$ & $360.80 \pm 0.17 \mathrm{a}$ & $5.25 \pm 0.06 \mathrm{a}$ & $5.19 \pm 0.17 \mathrm{a}$ \\
\hline
\end{tabular}

\section{Amino acids content and its chemical score of corn flakes and snacks:}

Chemical score of corn flakes and snacks were determined, based on the amount essential amino acids. For Further nutritional evaluation of prepared corn flacks, the amino acids content as presented in Table ( $7 \mathrm{a} \& 7 \mathrm{~b})$ results indicated that essential amino acids increased in corn flakes and snacks with increasing percentage addition white bean flour. 
Middle East J. Appl. Sci., 10(2): 390-406, 2020

Table 7a: Amino acids content and chemical score of prepared Corn Flakes:

\begin{tabular}{|c|c|c|c|c|c|c|c|}
\hline \multirow{2}{*}{\multicolumn{2}{|c|}{ Amino Acids }} & \multicolumn{2}{|c|}{ T 0} & \multicolumn{2}{|c|}{ T 1} & \multicolumn{2}{|c|}{ T 2} \\
\hline & & $\begin{array}{c}\mathrm{mg} / \mathrm{100} \\
\mathrm{g}\end{array}$ & $\begin{array}{l}\text { C.S } \\
(\%)\end{array}$ & $\begin{array}{c}\mathrm{mg} / \mathrm{100} \\
\mathrm{g}\end{array}$ & $\begin{array}{l}\text { C.S } \\
(\%)\end{array}$ & $\begin{array}{c}\mathrm{mg} / \mathrm{100} \\
\text { (g) }\end{array}$ & $\begin{array}{l}\text { C.S } \\
(\%)\end{array}$ \\
\hline \multirow{9}{*}{ 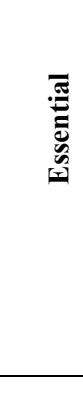 } & Valine & 40 & 0.8 & 55 & 1.1 & 58 & 1.16 \\
\hline & Isoleucine & 31 & 0.78 & 39 & 0.98 & 50 & 1.25 \\
\hline & Leucine & 82 & 1.17 & 95 & 1.36 & 97 & 1.39 \\
\hline & Lysine & 26 & 0.47 & 36 & 0.65 & 46 & 0.84 \\
\hline & Methionine & 19 & 0.54 & 21 & 0.60 & 24 & 0.69 \\
\hline & Phenylalanine & 37 & 0.62 & 46 & 0.77 & 52 & 0.87 \\
\hline & Threonine & 29 & 0.73 & 33 & 0.83 & 36 & 0.90 \\
\hline & Histidine & 24 & & 28 & & 31 & \\
\hline & T.E.A.A. & 228 & & 353 & & 394 & \\
\hline \multirow{9}{*}{ 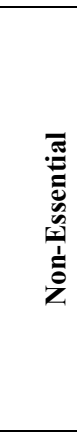 } & Alanine & 56 & & 66 & & 69 & \\
\hline & Arginine & 49 & & 56 & & 61 & \\
\hline & Aspartic Acid & 57 & & 76 & & 98 & \\
\hline & Cysteine & 17 & & 19 & & 20 & \\
\hline & Glutamic Acid & 120 & & 142 & & 188 & \\
\hline & Glycine & 34 & & 44 & & 47 & \\
\hline & Proline & 59 & & 60 & & 62 & \\
\hline & Serine & 37 & & 42 & & 44 & \\
\hline & Tyrosine & 37 & & 44 & & 48 & \\
\hline & N.E.A.A. & 466 & & 549 & & 637 & \\
\hline \multicolumn{2}{|c|}{ Total amino acids } & 754 & & 902 & & 1031 & \\
\hline
\end{tabular}

Table 7a: Continued:

\begin{tabular}{|c|c|c|c|c|c|c|c|c|}
\hline & Amino Acids & & & & & & & WHO/FAO \\
\hline & & $\begin{array}{c}\mathrm{mg} / \\
100 \mathrm{~g}\end{array}$ & C.S \% & $\begin{array}{c}\mathrm{mg} / \\
100 \mathrm{~g}\end{array}$ & C.S \% & $\begin{array}{c}\mathrm{mg} / \\
100 \mathrm{~g}\end{array}$ & C.S \% & $\begin{array}{l}\text { pattern for } \\
\text { (9-13 year) }\end{array}$ \\
\hline & Valine & 62 & 1.24 & 66 & 1.32 & 71 & 1.42 & 50 \\
\hline & Isoleucine & 52 & 1.30 & 59 & 1.48 & 64 & 1.6 & 40 \\
\hline 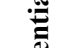 & Leucine & 101 & 1.44 & 108 & 1.54 & 116 & 1.66 & 70 \\
\hline$\underline{n}$ & Lysine & 47 & 0.85 & 62 & 1.13 & 71 & 1.29 & 55 \\
\hline & Methionine & 25 & 0.71 & 27 & 0.77 & 29 & 0.83 & 35 \\
\hline & Phenylalanine & 54 & 0.90 & 63 & 1.05 & 69 & 1.15 & 60 \\
\hline & Threonine & 44 & 1.10 & 50 & 1.25 & 56 & 1.40 & 40 \\
\hline & Histidine & 33 & & 37 & & 40 & & \\
\hline & T.E.A.A. & 418 & & 472 & & 516 & & \\
\hline & Alanine & 72 & & 79 & & 80 & & \\
\hline & Arginine & 64 & & 72 & & 79 & & \\
\hline & Aspartic Acid & 101 & & 119 & & 133 & & \\
\hline 茪 & Cysteine & 21 & & 24 & & 28 & & \\
\hline 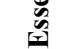 & Glutamic Acid & 199 & & 218 & & 235 & & \\
\hline $\bar{\Xi}$ & Glycine & 46 & & 51 & & 56 & & \\
\hline & Proline & 65 & & 66 & & 67 & & \\
\hline & Serine & 59 & & 64 & & 72 & & \\
\hline & Tyrosine & 44 & & 49 & & 51 & & \\
\hline & N.E.A.A. & 671 & & 742 & & 801 & & \\
\hline Tota & aino acids & 1089 & & 1214 & & 1317 & & \\
\hline
\end{tabular}


Table 7b: Amino acids content and chemical score of prepared Snacks:

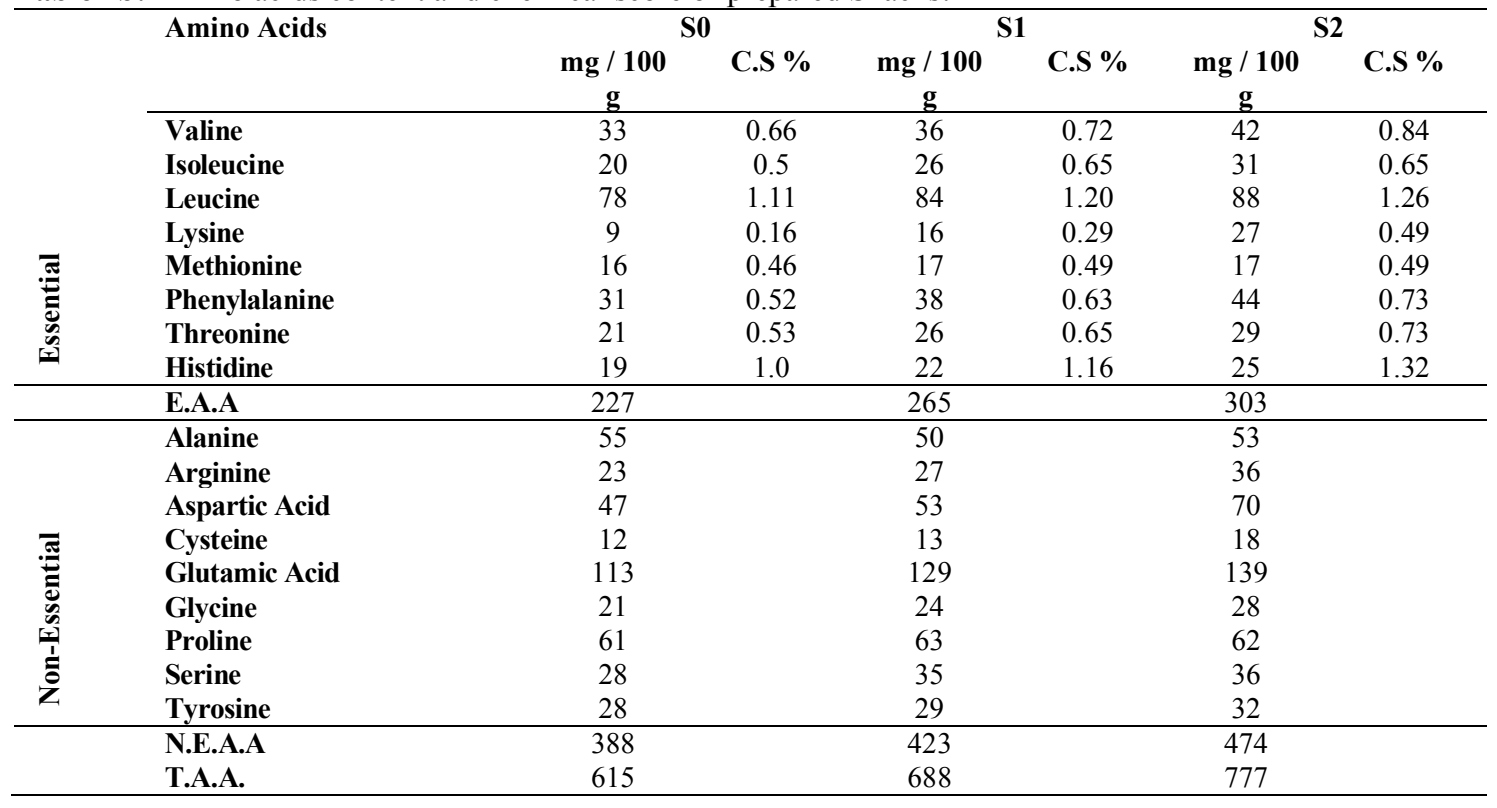

Table 7b: Continued

\begin{tabular}{|c|c|c|c|c|c|c|c|c|}
\hline & Amino Acids & & & & & & & WHO/FAO \\
\hline & & $\begin{array}{l}\mathbf{m g} / \\
100 \mathrm{~g}\end{array}$ & $\begin{array}{l}\text { C.S } \\
(\%)\end{array}$ & $\begin{array}{l}\mathbf{m g} / \\
\mathbf{1 0 0} \mathrm{g}\end{array}$ & $\begin{array}{l}\text { C.S } \\
(\%)\end{array}$ & $\begin{array}{l}\mathrm{mg} / \\
100 \mathrm{~g}\end{array}$ & $\begin{array}{l}\text { C.S } \\
(\%)\end{array}$ & $\begin{array}{l}\text { pattern for } \\
\text { (9-13 year) }\end{array}$ \\
\hline & Valine & 48 & 0.96 & 64 & 1.28 & 69 & 1.38 & 50 \\
\hline & Isoleucine & 37 & 0.78 & 43 & 0.93 & 47 & 1.08 & 40 \\
\hline & Leucine & 96 & 1.37 & 104 & 1.49 & 109 & 1.56 & 70 \\
\hline & Lysine & 38 & 0.69 & 43 & 0.78 & 43 & 0.78 & 55 \\
\hline & Methionine & 18 & 0.51 & 21 & 0.60 & 22 & 0.63 & 35 \\
\hline$\underline{E}$ & Phenylalanine & 51 & 0.85 & 57 & 0.95 & 62 & 1.03 & 60 \\
\hline$\tilde{n}$ & Threonine & 35 & 0.88 & 37 & 0.93 & 45 & 1.13 & 40 \\
\hline & Histidine & 29 & 1.53 & 32 & 1.68 & 35 & 1.84 & \\
\hline & E.A.A & 352 & & 401 & & 432 & & \\
\hline & Alanine & 58 & & 73 & & 77 & & \\
\hline & Arginine & 44 & & 53 & & 55 & & \\
\hline & Aspartic Acid & 84 & & 124 & & 120 & & \\
\hline & Cysteine & 17 & & 29 & & 16 & & \\
\hline$\ddot{\Xi}$ & Glutamic Acid & 156 & & 164 & & 187 & & \\
\hline$\ddot{n}$ & Glycine & 34 & & 42 & & 45 & & \\
\hline 5 & Proline & 64 & & 65 & & 68 & & \\
\hline$\Xi$ & Serine & 45 & & 38 & & 59 & & \\
\hline & Tyrosine & 36 & & 39 & & 40 & & \\
\hline & N.E.A.A & 538 & & 627 & & 667 & & \\
\hline & T.A.A. & 890 & & 1028 & & 1099 & & \\
\hline
\end{tabular}

The essential amino acids (EAA) content of two products were determined in comparison with that present in control samples. Results indicated that leucine represented the highest value in T 4, T5 and S 4, S5 for corn flacks and snacks while methionine represented the lowest value. Methionine being the most limiting amino acid in all samples for corn flacks and Snacks.

Also all nonessential amino acids content were amounts in T4, T 5 and S4, S5 for corn flakes and snacks $(742,801$ and $627,667 \mathrm{mg} / 100 \mathrm{~g})$ respectively compared with control samples were recorded 466 and $388 \mathrm{mg} / 100 \mathrm{~g}$ for corn flakes and snacks. Results indicated that glutamic acid represented the highest value of N.E.A.A. in all samples while, cysteine represented the lowest value in all samples for corn flakes and snacks.

As can be seen from the data in Table $7 \mathrm{a}$ and $7 \mathrm{~b}$, along with the supplementation of yellow corn in corn flakes and extruded snacks with broken white bean flour, noticed that increase in the total protein content of the final products was observed. More distinct changes were observed in products with increasing addition broken bean flour. Extrudates supplemented with broken bean flour at the 
level of 10, 20,30, 40 and 50\% respectively compared with traditional corn flakes and snacks. The data in Table $6 \mathrm{a}$ and $6 \mathrm{~b}$ also show that the addition of broken bean flour to the studied extrudates increased the content of essential amino acids such as lysine, methionine, cystine, leucine, isoleucine and valine and among nonessential amino acids glutamate content was observed. The supplementation of corn-based extrudates with broken bean flour affected to a higher degree the content of nonessential amino acids. The addition of experimental flour to corn-based extrudates resulted in the significant increase in the total essential amino acids along with increase in the level of supplementation.

\section{Nutritional value of corn flakes and snacks comparing with RDA from some nutrients for children aged $9-13$ years old.}

The percentages of the recommended dietary allowances (\% RDA) are provided from 100g of corn flakes and snacks for children are showed in table 8 . It could be observed that supplementation of corn flakes covers up to $38.85 \%$ of protein requirement, $22.3 \%$ and $25.09 \%$ of energy requirement for male and female, $29.44 \%$ of phosphorus requirement, $66.25 \%$ of iron requirement, $63.63 \%$ of zinc and $6.91 \%$ of calcium, for children. Whereas, snacks cover up to $33.44 \%$ of protein requirement, 22.52 $\%$ and $25.33 \%$ of energy requirement for male and female, $28.86 \%$ of phosphorus requirement, $65.63 \%$ of iron requirement, $64.88 \%$ of zinc and $6.24 \%$ of calcium, for children of age $9-13$ years. Therefore, it could be recommended to consume corn flakes and snacks to provide children with part of their daily requirements of protein, energy, phosphorus, calcium, iron and zinc.

Table 8: Nutritional Value of corn flakes and snacks /100g.

\begin{tabular}{llcccccc}
\hline Parameter & & \multicolumn{5}{c}{ \% RDA of Corn flakes } \\
\cline { 3 - 7 } & & T0 & T1 & T2 & T3 & T4 & T5 \\
\hline Protein & & 22.17 & 23.58 & 31.35 & 33.32 & 36.53 & 38.85 \\
Fibers & Male & 8.29 & 8.1 & 6.19 & 6 & 5.39 & 3.13 \\
& Female & 9.88 & 9.65 & 7.38 & 7.15 & 6.42 & 3.73 \\
\hline Carbohydrates & & 66.3 & 65.78 & 63.81 & 63.32 & 62.38 & 61.72 \\
Energy & Male & 22.7 & 22.6 & 22.53 & 22.48 & 22.41 & 22.3 \\
& Female & 25.53 & 25.43 & 25.35 & 25.29 & 25.21 & 25.09 \\
\hline & Ca & 3.53 & 4.68 & 5.31 & 5.69 & 6.22 & 6.91 \\
& P & 18.23 & 23.75 & 25.12 & 26.49 & 28.71 & 29.44 \\
& Fe & 41.13 & 43.00 & 49.38 & 54.38 & 61.88 & 66.25 \\
& Zn & 18.50 & 28.50 & 38.63 & 49.38 & 56.88 & 63.63 \\
\hline
\end{tabular}

Table 8: Continued

\begin{tabular}{llcccccc}
\hline Parameter & & \multicolumn{5}{c}{ \% RDA of Snacks } \\
\cline { 3 - 7 } Protein & & S0 & S1 & S2 & S3 & S4 & S5 \\
\cline { 3 - 7 } Fibers & Male & 18 & 22.26 & 24.44 & 28.91 & 30.5 & 33.44 \\
& Female & 1.35 & 1.52 & 2.97 & 3.65 & 4.29 & 4.94 \\
\hline Carbohydrates & & 1.62 & 1.81 & 3.54 & 4.35 & 5.12 & 5.88 \\
\multirow{2}{*}{ Energy } & Male & 70.82 & 69.18 & 68.22 & 66.69 & 66.01 & 64.98 \\
& Female & 22.56 & 22.55 & 22.57 & 22.52 & 22.49 & 22.52 \\
& Ca & 25.38 & 25.37 & 25.39 & 25.34 & 25.3 & 25.33 \\
& P & 3.44 & 4.65 & 5.38 & 5.55 & 6.14 & 6.24 \\
& Fe & 19.77 & 23.66 & 25.61 & 27.21 & 28.23 & 28.86 \\
& Zn & 41.63 & 43.38 & 48.75 & 53.75 & 60.88 & 65.63 \\
& & 17.75 & 27.50 & 39.88 & 48.75 & 57.13 & 64.88 \\
\hline
\end{tabular}

\section{Sensory evaluation:}

Sensory evaluation of corn flacks and snacks taste, odor texture, color, and overall acceptability of the extruded samples and control. Corn flacks and snacks were evaluated by a sensory panel and the results are reported in Table (9). The taste ratings for corn flacks and snacks ranged from 7.73 to 7.33 and 7.30 to 6.60 which indicates that formulation $\mathrm{T} 1$ and $\mathrm{S} 1$ had the highest rating from all the samples. T3, T4 and S3, S4 were not significantly different $(p>0.05)$ from each other and were neither liked nor disliked by the panellists. Differences in taste can be attributed to molecular changes in the flour due to the different processing conditions (soaking, dehulling and drying) that the raw materials specially broken white bean BWB were subjected to Fellows, (2009).

In terms of odor, product $T_{1}$ and $S_{1}$ were rated the highest (7.90 and 7.60) $T_{5}, S_{5}(7.30$ and 7.00) were the lowest as shown, significant difference $(p>0.05)$ existed between all samples for snacks. The 
odor of corn flakes and snacks from yellow corn and BWB formulations were liked by the panellists and they slightly neither liked $T_{5}$ for corn flakes nor disliked $\mathrm{S}_{5}$ for snacks. The mean scores indicated that, the panelists were found to like more breakfast meals corn flakes and snacks with BWB flour substitution from 10 to $30 \%$. This may be due to panellists'familiarity with the smell of maize and beans blends. As reported by Enwere (1998) meals prepared from un-dehulled beans may possess a beany odor which may be disliked by consumers. However, panellists did not detect any beany odor in the products, which indicates that the processing of the broken beans was able to remove the undesirable beany odor associated with beans products (Ampofo, 2009).

Mean score for texture of the corn flakes and extruded snacks prepared from the yellow corn and BWB flour formulations were within the range of 7.73 to 6.23 for corn flakes and 8.50 to 6.25 for snacks. There were significant differences $(p>0.05)$ amongst the formulated corn flakes and extruded snacks. This indicates that, T1, S1 to T4, S4 were liked. Panellists neither liked nor disliked the texture of T5 and S5. Texture of corn flakes and extruded snacks could be attributed to the high ratio of BWB flour content in blends.

Color, the mean scores from 8.71 to 6.47 and 7.60 to 6.90 were ranked by Panellists which indicate that the color of the formulations were liked and slightly liked for T5, S5. T0, S0 (control) had the highest ranking for color. In the formulations group products T1, S1 was highly rated followed by T2, S2. There was no significant different $(p>0.05)$ existing between them. Variations in the rating could be attributed to the chemical composition of the raw materials, the drying temperature and duration, as well as ratio of substitution of the individual flours (Belitz et al., 2009; Fellows, 2009).

(McDonough et al., 2004) also reported that browning reactions can occur during processing of cereal grains which can impart on the color of cereal flours and meals prepared from them.

The overall acceptability of the formulations ranged from 8.46 to 7.53 and 8.00 to 7.60 for corn flakes and snacks respectively. The highest overall acceptability rating were recorded for T1 and S1 which were significantly different $(p<0.05)$ from the others. Significant differences $(p>0.05)$ were recorded for formulations $T_{2}, T_{3}$ and $S_{2}, S_{3}$.

The results revealed that addition of BWB flours to corn flakes and snacks formulated significantly improved their overall acceptability to $30 \%$. High overall acceptability values indicate that the product has good chances of being patronized by consumers when launched on the market (Asante, 2015). Thus, formulation $T_{1}, S_{1}$ and $T_{2}, S_{2}$ can compete with formulation $T 0$ (control) on the market. Similar results showed that the sensory evaluation had the lowest overall acceptability scores for the extruded samples No T5 and S5 for corn flacks and snacks.

Table 9: Sensory evaluation of prepared Corn Flakes and extruded Snacks:

\begin{tabular}{llllll}
\hline Treatment & $\begin{array}{l}\text { Taste } \\
(\mathbf{9})\end{array}$ & $\begin{array}{l}\text { Odor } \\
\text { (9) }\end{array}$ & $\begin{array}{l}\text { Texture } \\
\text { (9) }\end{array}$ & $\begin{array}{l}\text { Color } \\
(\mathbf{9 )}\end{array}$ & $\begin{array}{c}\text { Overall acceptability } \\
\text { (9) }\end{array}$ \\
\hline & & & Corn Flakes & & \\
T0 & $8.00 \pm 0.50 \mathrm{a}$ & $8.00 \pm 0.50 \mathrm{a}$ & $8.00 \pm 0.50 \mathrm{a}$ & $8.73 \pm 0.25 \mathrm{a}$ & $8.50 \pm 0.50 \mathrm{a}$ \\
T1 & $7.73 \pm 0.75 \mathrm{a}$ & $7.90 \pm 0.81 \mathrm{a}$ & $7.73 \pm 0.25 \mathrm{a}$ & $8.71 \pm 0.26 \mathrm{a}$ & $8.46 \pm 0.50 \mathrm{a}$ \\
T2 & $7.52 \pm 0.50 \mathrm{a}$ & $7.80 \pm 0.60 \mathrm{ab}$ & $6.93 \pm 0.51 \mathrm{~b}$ & $8.52 \pm 0.50 \mathrm{a}$ & $8.42 \pm 0.14 \mathrm{a}$ \\
T3 & $7.47 \pm 0.50 \mathrm{a}$ & $7.79 \pm 0.51 \mathrm{ab}$ & $6.50 \pm 0.50 \mathrm{~b}$ & $7.97 \pm 0.50 \mathrm{ab}$ & $8.00 \pm 0.08 \mathrm{ab}$ \\
T4 & $7.36 \pm 0.29 \mathrm{a}$ & $7.47 \pm 0.50 \mathrm{bc}$ & $6.43 \pm 0.51 \mathrm{~b}$ & $7.17 \pm 0.76 \mathrm{bc}$ & $7.97 \pm 0.06 \mathrm{ab}$ \\
T5 & $7.33 \pm 0.29 \mathrm{a}$ & $7.30 \pm 0.25 \mathrm{c}$ & $6.23 \pm 0.25 \mathrm{~b}$ & $6.47 \pm 0.50 \mathrm{c}$ & $7.53 \pm 0.50 \mathrm{~b}$ \\
\hline & & & Extruded Snacks & & \\
S0 & $7.35 \pm 0.26 \mathrm{a}$ & $7.70 \pm 0.50 \mathrm{a}$ & $8.50 \pm 0.50 \mathrm{a}$ & $7.60 \pm 0.26 \mathrm{a}$ & $8.10 \pm 0.50 \mathrm{a}$ \\
S1 & $7.30 \pm 0.29 \mathrm{a}$ & $7.60 \pm 0.41 \mathrm{a}$ & $8.50 \pm 0.00 \mathrm{a}$ & $7.60 \pm 0.06 \mathrm{ab}$ & $8.00 \pm 0.50 \mathrm{a}$ \\
S2 & $7.20 \pm 0.25 \mathrm{a}$ & $7.50 \pm 0.30 \mathrm{a}$ & $8.00 \pm 0.50 \mathrm{ab}$ & $7.50 \pm 0.00 \mathrm{ab}$ & $7.90 \pm 0.50 \mathrm{a}$ \\
S3 & $7.00 \pm 0.50 \mathrm{a}$ & $7.30 \pm 0.21 \mathrm{a}$ & $7.79 \pm 0.26 \mathrm{~b}$ & $7.10 \pm 0.06 \mathrm{c}$ & $7.30 \pm 0.06 \mathrm{~b}$ \\
S4 & $7.00 \pm 0.50 \mathrm{a}$ & $7.20 \pm 0.31 \mathrm{~b}$ & $6.93 \pm 0.12 \mathrm{c}$ & $7.03 \pm 0.25 \mathrm{c}$ & $7.00 \pm 0.25 \mathrm{~b}$ \\
S5 & $6.60 \pm 0.26 \mathrm{a}$ & $7.00 \pm 0.25 \mathrm{c}$ & $6.25 \pm 0.25 \mathrm{~d}$ & $6.90 \pm 0.04 \mathrm{~d}$ & $6.60 \pm 0.09 \mathrm{c}$ \\
\hline
\end{tabular}



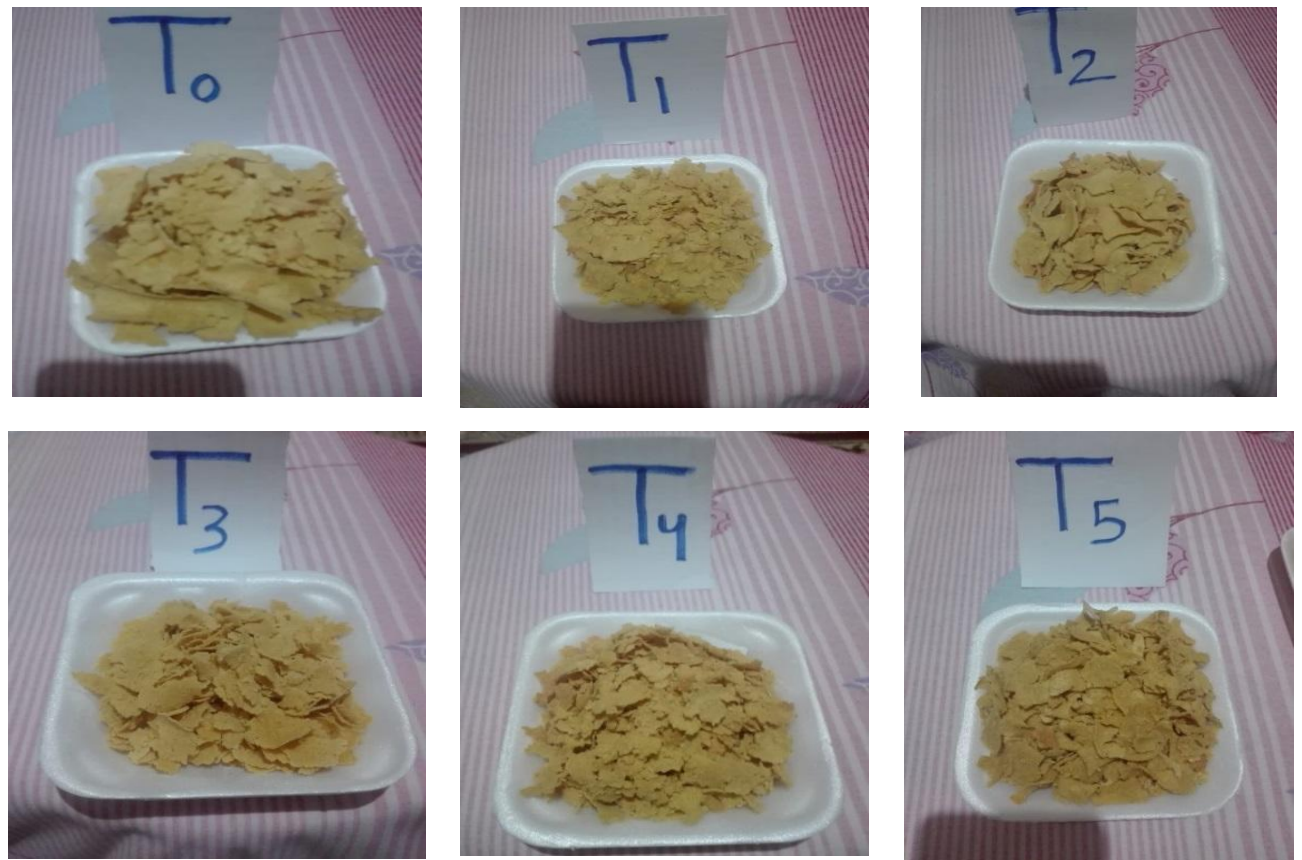

Fig. 1: Corn flakes made by using different concentrations from BWBF

T0:100\% corn flour and zero $\%$ BWBF. T1: $90 \%$ corn flour and 10\% BWBF. T2: $80 \%$ corn flour and $20 \%$ BWBF. T3: 70\% corn flour and 30\% BWBF. T4: $60 \%$ corn flour and 40\% BWBF. T5: 50\% corn flour and 50\% BWBF.
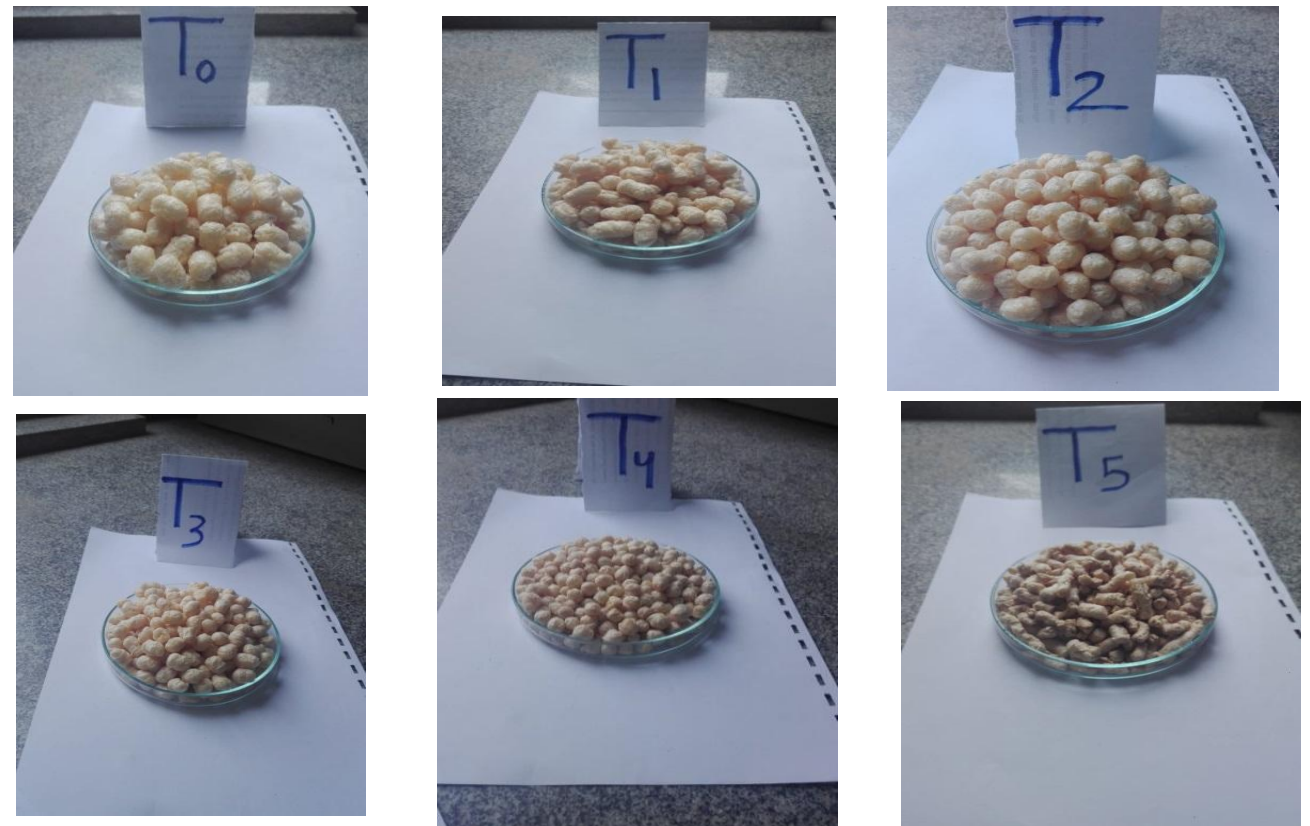

Fig. 2: snacks made by using different concentrations from $B W B F$

T0:100\% corn grits and zero $\%$ BWBF. T1: $90 \%$ corn grits and $10 \%$ BWBF. T2: $80 \%$ corn grits and $20 \%$ BWBF. T3:70\% corn grits and $30 \%$ BWBF. T4: $60 \%$ corn grits and $40 \%$ BWBF. T5: $50 \%$ corn grits and $50 \%$ BWBF.

\section{Production costs of different treatments corn flakes and extruded snacks: (L.E./Kg)}

Production costs of different samples were calculated and presented in Table (10). Data obtained showed that the cost reduction (\%) noticeably increased as the ascriptions of broken white bean flour increased in the blend. From this table it could be noticed that, the cost for one $/ \mathrm{kg}$ of the control samples were high costs, the total cost was 12.30 and $11.60 \mathrm{EGP} / \mathrm{kg}$ for corn flakes and extruded snacks .The highest cost price for the corn flakes samples Group (1) $\mathrm{T}_{1}$, the cost one $\mathrm{kg}$ were average (12.25 to 14.75 
EGP/kg).The average price for samples Group (2) extruded snacks were (11.38 to 13.88). These prices are plausibly accepted when compared with the prices for commercial products such as (Temmy's and prada corn flakes) ranged from 72 to $80 \mathrm{EGP} / \mathrm{kg}$ compared with sample group(1). While the commercial samples (windows) cost average 55.56 EGP/ kg compared with group samples (2). The investigated extrudates were completely cheaper and could be offered to consumers at a price of about quarter to third of market snacks.

It could be found that the prices are very suitable for the Egyptian market and thus these results and sensory evaluation recommend that the best rate is to add 10 to $30 \%$ experimental panelists for corn flakes snacks.

Table 10: Production costs of different treatments (L.E./Kg).

\begin{tabular}{|c|c|c|c|c|c|c|c|}
\hline \multirow[b]{2}{*}{ Group No. } & \multirow[b]{2}{*}{ Treatment } & \multicolumn{6}{|c|}{ Price (L.E.) } \\
\hline & & $\begin{array}{c}\text { Kg of } \\
\text { Ingredient }\end{array}$ & $\begin{array}{l}\text { Electricity } \\
\text { and water }\end{array}$ & Service & $\begin{array}{c}\text { Collection } \\
\text { of cost }\end{array}$ & $\begin{array}{c}\text { Profit } \\
\% 25\end{array}$ & $\begin{array}{c}\text { Kg of } \\
\text { market } \\
\text { samples }\end{array}$ \\
\hline \multirow{7}{*}{$\begin{array}{c}\text { Group } \\
\text { (1) }\end{array}$} & & \multicolumn{6}{|c|}{ Corn Flaks } \\
\hline & T0 & 5.80 & 1.50 & 5.00 & 12.30 & 3.18 & 15.38 \\
\hline & T1 & 5.30 & 1.50 & 5.00 & 11.80 & 2.95 & 14.75 \\
\hline & T2 & 4.80 & 1.50 & 5.00 & 11.30 & 2.83 & 14.13 \\
\hline & T3 & 4.30 & 1.50 & 5.00 & 10.80 & 2.7 & 13.50 \\
\hline & T4 & 3.80 & 1.50 & 5.00 & 10.30 & 2.58 & 12.88 \\
\hline & T5 & 3.30 & 1.50 & 5.00 & 9.80 & 2.45 & 12.25 \\
\hline & & \multicolumn{6}{|c|}{ Extruded snacks } \\
\hline & T0 & 5.10 & 1.50 & 5.00 & 11.60 & 2.9 & 14.50 \\
\hline & $\mathbf{T 1}$ & 4.60 & 1.50 & 5.00 & 11.10 & 2.78 & 13.88 \\
\hline Group & $\mathbf{T 2}$ & 4.10 & 1.50 & 5.00 & 10.60 & 2.65 & 13.25 \\
\hline \multirow[t]{3}{*}{ (2) } & T3 & 3.60 & 1.50 & 5.00 & 10.10 & 2.53 & 12.63 \\
\hline & T4 & 3.10 & 1.50 & 5.00 & 9.60 & 2.40 & 12.00 \\
\hline & T5 & 2.60 & 1.50 & 5.00 & 9.10 & 2.28 & 11.38 \\
\hline Temmy's corn & & & & & & & 72.00 \\
\hline flakes prada & & & & & & & 80.00 \\
\hline corn flakes & & & & & & & \\
\hline (like Group1) & & & & & & & \\
\hline Window & & & & & & & 55.56 \\
\hline
\end{tabular}

\section{Conclusion}

In this study, the high percentages of white bean flour, from a nutritional point of view, contribute to increasing the protein content in the extruded products; however, lower amounts of white bean flour, may be more beneficial to achieve better expansion.

From the obvious results, it could be concluded that the extruded corn flacks and snacks showed an increase in protein and minerals than that control corn flacks and snacks. Moreover, physical characteristics, water absorption index of extruded corn flacks and snacks than control. Also, the sensory evaluation showed that the samples No. T4, S4 and T5, S5 (the lowest in overall acceptability scores in corn flacks extruded snacks) may be due to the increasing concentration of BWB powder. Extruded blends No.T1, S1 toT3 S3 made from 10 to 30\% broken white beans flour were most like by the taste panelists.

\section{Acknowledgement:}

The authors of this study thank Dr. Hanan Hussien professor of Department of Bread and Pastry Research, and Dr. Nady Abd El- Aziz Doctor of Food Processing Economic Research Unit, Food Technology Research Institute, Agricultural Research Centre for their effort provided through this work.

\section{References}

A.O.A.C. 2016. Official Methods of Analysis of the Association of Official Analytical Chemists, $20^{\text {th }}$ ed, Arligton, Virginia, USA. 
Abd Rabo, F., A. M. Azzam, and M.O. Dewidar, 2019. Whey/Broken Chickpea Extract for Manufacture of Probiotic Frozen Yoghurt. Curr. Res. Nutr Food Sci Jour., 7(3): 807-818.

Agriculture Directorates of Governorates Statics, 2015. Economic Affairs Sector. Curr. Sci. Int., 6(3): 670-683, 2017.

Aguilar-Palazuelos, E., J. D. J. Zazueta-Morales, E. N. Harumi, and F. Martínez-Bustos, 2012. Optimization of extrusion process for production of nutritious pellets. Food Science and Technology, 32(1): 34-42.

Algarni, E.H., H.A. Hussien, and E.M. Salem, 2019. Development of Nutritious Extruded Snacks. Life Science Journal, 16(9):23-31.

Al-Subhi F. M., 2014. Using Extrusion to Prepare Snacks Food High Nutrition Value Fortified with Soybean and Spinach for Children Middle East Journal of Applied Sciences, 4(4): 959-966, ISSN: 2077-4613

Ampofo, V. 2009. Production and sensory analysis of soybean and wheat flour composite cake. HND Dissertation, Cape Coast Polytechnic, Cape Coast, Ghana. 1: 5-7.

Anderson R. A., H. F. Conway and E. L. Griffin, 1969. Gelatinization of corn grits by roll and extrusion cooking. Cereal Science Today Cereal Science Today: (14) 4-12.

Areas, J. A. G., C. M. Rocha-Olivieri, and M. R. Marques, 2016. Extrusion cooking: Chemical and nutritional changes. In B. Caballero, P. M. Finglas, \& F. Toldra (Eds.), Encyclopedia of Food and Health, 569-575.

Asante, F. A., 2015. Process development and evaluation of tiger nut based chocolate products, [dissertation]. Kumasi: Kwame Nkrumah University of Science and Technology, 57.

Bastos-Cardoso, I., J. de J. Zazueta-Morales, F. Martínez-Bustos, and Y. Kil-Chang, 2007. Development and characterization of extruded pellets of whole potato (Solanum tuberosum L.) flour expanded by microwave heating. Cereal chemistry, 84(2): 137-144.

Belitz, H. D., W. Grosch and P. Schieberle, 2009 . Food chemistry. Springer, 4th. Springer-Verlag: Berlin, Vol. 173, 959-966. doi: 10.1007/978-3-540-69934-7.

Bolanho, B. C., E. D. G. Danesi, and A. P. Beleia, 2014 . Characterization of flours made from peach palm (Bactris gasipaes Kunth) by-products $\mathrm{s}$ a new food ingredient. Journal of Food and Nutrition Research, 53(1): 51-59.

Broughton,W. J., G. Hernandez, M. Blair, S. Beebe , P. Gepts, and J. Vanderleyden, 2003 . Beans (Phaseolus spp.)-model food legumes. Plant and Soil, 252:55-128.

Bulletin of The Agricultural Statistics 2018. Part 2 Summer and Nili Crops. Ministry of Agriculture and Land Reclamation. ARE.

Cabrera, C., F. Lloris, R. Gimez, M. Olalla and M. C. Lez, 2003 . Mineral content in legumes and nuts: Contribution to the Spanish dietary intake. Sci. Total Environ. 308:1-14.

Camara, S.R.C., A.U. Urrea, and V. Schlegel, 2013. Pinto Beans (Phaseolus vulgaris L.) as a Functional Food: Implications on Human Health. Agriculture, 3(1): 90-111.

Camire, M. E. and C. C. King, 1991. Protein and fiber supplementation effects on extruded cornmeal snack quality. Journal of Food Science, 56: 760-763.

Carreiro, A., A. Godoy, A. C. Lima, C. Tavares, D. Lopes and V. A. Magalhães, 2008. Alimentos extrusados. São Paulo: Faculdade de Ciências Farmacêuticas, Universidade de São Paulo.

Carvalho A. V., A. M. Rafaella de, Z. B. Priscilla, N. K. Selma, O. R. Alessandro de, A. M. Renan de and N. C. Rosangela, 2012. Processing and characterization of extruded breakfast meal formulated with broken rice and bean flour. Ciência e Tecnologia de Alimentos. 32(3):515-524.

Ding, Q.B., P. Ainsworth, A. Plunkett, G. Tucker and H. Marson, 2005. The effect of extrusion conditions on the physicochemical properties and sensory characteristics of rice-based expanded snacks. Journal of Food Engineering 66: 283-289.

Ding, Q.B., P. Ainsworth, A. Plunkett, G. Tucker and H. Marson, 2006: The effect of extrusion conditions on the functional and physical properties of wheat based expanded snacks. Journal of Food Engineering, 73: 142-148.

Enwere, N. J., 1998. Foods of plant origin: Processing and utilization, 224-232. Nsukka: Afro-Orbis Publications Ltd.

Estrada-Girón, Y., A.H. Martínez-Preciado, C.R. Michel, and J.F.A. Soltero, 2015. Characterization of extruded blends of corn and beans (Phaseolus vulgaris) cultivars: Peruano and black-querétaro under different extrusion conditions. International journal of food properties, 18(12): 2638-2651. 
FAO/WHO, 1991. Protein quality Evaluation Reports of a joint FAO/WHO expert Consultation, Food and Agriculture Organzation of the United Nations, FAO, Rome.

Fellows, P. J., 2009. 15 - Extrusion BT - food processing technology, 2nd. Woodhead publishing series in food science, technology and nutrition, 456-477. doi: 10.1533/9781845696344.3.456

Filipovic J., L. Pezo , N. Filipovic, V. Filipovic , J. Brkljaca, and J. Krulj, 2015 LWT - Food Sci. Technol. 63 (43) Functional Food: Journal Agriculture 3, 90-111; doi:10.3390/agriculture 3010090 Implications

Forsido, S. F., H. T. Duguma, T. B. Lema, B. Sturm , and O. Hensel, 2019 . Nutritional and sensory quality of composite extruded complementary food. Food science \& nutrition, 7(2), 882-889. https://doi.org/10.1002/fsn3.940

Gomes, L. D. O. F., R. D. A. C. Santiago, A. V. Carvalho, R. N. Carvalho, I. G. D. Oliveira and P. Z. Bassinello, 2015 . Application of extruded broken bean flour for formulation of gluten-free cake blends. Food Science and Technology, 35(2): 307-313.

IBM Corp. Released. 2011. IBM SPSS Statistics for Windows, Version 20.0. Armonk, NY: IBM Corp.

Jones, D., R. Chinnaswamy, Y. Tan, and M. Hanna, 2000. Physicochemical properties of ready-to-eat breakfast cereals. Cereal Food World, 45: 164-168.

Kabil, E.M.I., 2016. Studies on the production of some healthy foods for school students. Ph.D. Thesis, Fac. Agric., Moshtohor, Benha, Univ.

Kaludjerski G. and N. Filipović, 1998. Methods for the investigation of cereals, flour and final product quality, Faculty of Technology, Novi Sad, p. 291 (in Serbian)

Kamau E. H., S. G. Nkhata and E.O. Ayua, 2020. Extrusion and nixtamalization conditions influence the magnitude of change in the nutrients and bioactive components of cereals and legumes. Food Sci Nutr.;00:1-14.

Kannadhason S., K. Muthukumarappan and K. A. Rosentrater, 2009. Journal of Aquaculture Feed Science and Nutrition 1 (1): 6-21.

Kerolles, S. Y., 1986. The pectic substances.Intercience Publishers, Inc., NewYrok.

Košutić M, J. Filipović1, L. Pezo, D. Plavšić and M. Ivkov, 2016. Physical and sensory properties of corn flakes with added dry residue from wild oregano distillation J. Serb. Chem. Soc. 81(9): $1013-1024$

Kummu, M., H. de Moel, M. Porkka, S. Siebert, O. Varis and P. J. Ward, 2012 . Lost food, wasted resources: Global food supply chainlosses and their impacts on freshwater, cropland, and fertilizer use. Science of The Total Environment, 438: 477-489. https://doi. org/10.1016/j.scitotenv.2012.08.092.

Lewicki, P. P., A. Marzec and M. Kuropatwa, 2007 . Influence of water activity on texture of corn flakes. Acta Agrophysica, 9(1):79-90.

Li Y., K.M. Kloeppel, F. Hsieh, 1998. Texture of glassy corn cakes as a function of moisture content. Journal of Food Sci., 5, 869-871,

Liene S. and M.B. Sandra 2016. The Characteristics of Extruded Faba Beans (Vicia faba L.) Rural Sustainability Research 36 (331): 42 - 48. ISSN - 2256-0939.

Lopes, L. C. M., K. A. Batista, K. F. Fernandes and R. A. C. Santiago, 2012 . Functional, biochemical and pasting properties of extruded bean (Phaseolus vulgaris) cotyledons. International Journal of Food Science \& Technology, 47(9): 1859-1865. http://dx.doi.org/10.1111/ j.13652621.2012.03042.x.

Lu, S. and C.E. Walker, 1988. Laboratory preparation of ready to eat breakfast. . J. Am. Assoc. Cereal Chem. 65(4):377-379.

McDonough, C. M., C. D. Floyd, R. D. Waniska, and L. W. Rooney, 2004. Effect of accelerated aging on maize, sorghum, and sorghum meal. Journal of Cereal Science, 39(3): 351-361. doi:10.1016/j. jcs.2004.01.001.

Nwabueze, T. U., M. O. Iwe, and E. N.T. Akobundu, 2008. Physical characteristics and acceptability of extruded African breadfruit-based snacks. Journal of Food Quality, 31(2):142-155.

Ocheme, O. B., C.C. Ariahu and M. O. Igyor, 2011 . Assesment of traditionally produced Dakuwa (A cereal/legume based Nigerian snack) in Niger state, Nigeria. Nigerian Food Journal, 29(1):6369.

Ojijo, N. K. O., T. Kimura, and H. Koazei, 2000. Composition, soaking and softening characteristics of some Kenyan beans (Phaseolus vulgaris L.). Food Sci. Tech, Res. 6(I):12-18. 
Pelembe, L. A. M., C. Erasmus, and J. R. N. Taylor, 2002. Development of a protein-rich composite sorghum-cowpea instant porridge by extrusion cooking process. LWT - Food Science and Technology, 35(2), 120-127. http://dx.doi.org/10.1006/fstl.2001.0812.

Ramezani, S., S. Movahhed, and P. Rajaei, 2013. Effect of additional white bean flour on chemical and staling properties of Iranian industrial and traditional barbari breads. Annals of Biological Resource, 4, 109-112.

Rezende, A.A., B.T.M. Pacheco, D.N.S.V. Aparecida, and D.P. Ferreira, 2018 .Nutritional and protein quality of dry Brazilian beans (Phaseolus vulgaris L.)Food Sci. Technol, Campinas, 38(3): 421427.

Rouf Shah, T., K. Prasad, and P. Kumar, 2016. Maize a potential source of human nutrition and health: A review. Cogent Food \& Agriculture (2016), 2: 1166995. http://dx.doi.org/10.1080/23311932.2016.1166995.

Sagar, N. A., S. Pareek, S. Sharma, E. M. Yahia and M. G. Lobo, 2018. Fruit and vegetable waste: Bioactive compounds, their extraction, and possible utilization. Comprehensive Reviews in Food Science and Food Safety, 17, 512-531. https://doi.org/10.1111/1541-4337. 12330.

Santos, L.I., M. Schmiele, L.P.J. Aguiar, J.C. Steel, P.E. Siliva, and A.C.F. Souza, 2020. Evaluation of extruded corn breakfast cereal enriched with whole peach palm (Bactris gasipaes, Kunth) Flour. Food Sci. Technol, Campinas, 40(2): 458-464.

Shimelis, E. A. and S. K. Rakshit, 2005. Proximate composition and physicochemical properties of improved dry bean (Phaseolus vulgaris L.) varieties grown in Ethiopia. LWT. 38:331-338.

Tharanathan, R. N. and S. Mahadevamma, 2003. Grain legumes - a boon to human nutrition. Trends in Food Science \& Technology, 14(12): 507-518.

Universidade Estadual de Campinas - UNICAMP. 2011. Tabela brasileira de composição de alimentos - TACO (4th Rev. ampl. ed.). Campinas: Unicamp/NEPA.

Vadivel, V. and K. Janardhanan, 2000. Nutritional and anti-nutritional composition of velvet bean: An under-utilized food legume in South India. Int. J.Food Sci. Nutr. 51:279-287.

Welch, R. M., House, W. A., Beebe S. and Cheng, Z.(2000). Genetic selection for enhanced bioavailable levels of iron in bean (Phaseolus vulgaris L.) seeds. J. Agric. Food Chem. 48:35763580 .

Wojtowicz, A., and L. Moscicki, 2014. Influence of legume type and addition level on quality characteristics, texture and microstructure of enriched precooked pasta, LWT - Food Science and Technology, http://dx.doi.org/10.1016/j.lwt.2014.06.010

Wu, X. F., R. James, and A. K. Anderson, 2005. Mineral contents in seed coat and canning quality of selected cultivars of dark red kidney beans (Phaseolus vulgaris L.). J. Food Process Preserv. 29(1):63-74.

Yagci, S. and F. Gogus, 2008. Development of extruded snack from food by-products: a response surface analysis. Journal of Food Process Engineering 32(4): 565 - 586. 